\title{
Governance and school boards in non-state schools in Australia
}

\begin{abstract}
The paper explores governance arrangements in non-state school in Australia, using seventeen interviews in six schools. The focus is on board composition, structure and reporting. Useful contributions about innovative practice are identified. School boards may benefit from implementing more stakeholder engagement. Existing models of school boards from international state school literature, such as the democracy and trustee models, were useful for describing some aspects of non-state school governance, but a faith model is also suggested. Further research could operationalise governance elements to conduct a quantitative investigation with more schools and more informants. The paper adds to the expanding international literature on schools governance by researching a country that has received little governance attention. The paper focuses on a significant area for school leadership: school boards in non-state schools.
\end{abstract}

Key words: School boards, decentralisation, governance, non-state schools, faith model 


\section{Introduction}

Governance has changed over time, reflecting shifts in state ideology and policy (Ball, 2009), and new global and supranational pressures (Engel, 2008). Good governance is vital to the health and functioning of schools (Gruber, 1999). International literature focuses on devolving central control of state schools to local communities in various national contexts, with new forms of governance (Addi-Raccah \& Gavish, 2010; Dahlstedt, 2009; Grant, 2006; Lo \& Gu, 2008; London, 2010; Ranson, 2008). The nature and consequences of governance shifts vary, with research generally reporting decentralisation and local involvement (Edwards, 2010; Storey \& Farrar, 2009). There is also a move for schools to adopt business models of governance (Eacott, 2008).

Analysing definitions of governance leads to the following: most imply both structures and processes, including decision making (Amey et al., 2008; Stoker, 1998), ordered rule and compliance (Ranson, 2008; Salleh et al., 2009), accountability and responsibility to, and involvement of, a range of stakeholders (Ackerman, 2004; Alfred \& Smydra, 1985), and collective action (Stoker, 1998), in achieving a purpose or objectives (Coyle, 2004). The definition of governance adopted here combines these as follows: structures, processes and collective action, in order to fulfil responsibility and accountability to a range of stakeholders in achieving the purpose and objectives of the school. The governing body is usually the school board or school council, and the term board is adopted here for convenience.

The present paper addresses governance in non-state schools, in one state of Australia (Queensland). It contributes understanding of governance processes in nonstate schools, in contrast to much of the extant literature on state schools (Allan, 2006; 
Youngs et al., 2007). Further, there is limited Australian research on school governance (Brewer \& Smith, 2008). Best practice in school governance needs to be identified and published (Allan, 2006; Bush \& Gamage, 2001).Non-state schools, virtually by definition, have been free from government control, but in Queensland, have recently been subject to new regulations, implying new demands for accountability and responsibility.

\section{Governance elements}

According to Newell and Wilson (2002) there are at least ten elements of good governance, and this paper focuses on a selection that provides for a detailed description of board composition. A large part of governance is managing for, and being accountable to, a variety of stakeholders (Carver, 1997; Donaldson \& Preston, 1995; Kiel \& Nicholson, 2003; Picou \& Rubach, 2006; Zattoni \& Cuomo, 2008). Schools have a responsibility to communicate effectively with stakeholders (BRT, 2002; Zattoni \& Cuomo, 2008). The board is also responsible for monitoring its own accountability (OECD, 1999; Picou \& Rubach, 2006). Around five to nine is the optimal number of members (Newell \& Wilson, 2002), while a governance committee should evaluate board processes including nomination of members (Picou \& Rubach, 2006). While not-for-profit boards undertake evaluation of the chief executive officer (principal), they have not been as conscientious in evaluating their own performance (Tweeten, 2002). This evaluation includes the process for recruiting and inducting new members, during which the board should identify the required skills mix for its members (Kiel \& Nicholson, 2003). Expectations should be clearly 
enunciated to prospective members and new members should be formally inducted. General practice is for the board to select the principal (Picou \& Rubach, 2006).

\section{Local context of the study}

There is limited Australian research on school governance (Brewer \& Smith, 2008), although Hay (2009) argues that trends in Australia are similar to overseas, in terms of converging international policy, increasing school autonomy and new regulatory regimes.

The current trends in Australia include increased federal intervention and regulation for performance (publishing league tables, introducing national curriculum) (ACARA, 2009) and devolution at state level (principals hiring their own staff in some states). Each state is responsible for funding and regulating its own schools (Banks, 2005), and unlike in the UK, local government plays no role. This research is set in Queensland: one state of Australia, where in this state, schools are nominally either state (government run and government funded, also known as public) or non-state. This research is concerned with non-state schools, which are not charter schools (autonomous US state-schools). One Australian state (Victoria) has a version of this school type (Turkington, 1998). Although non-state are known as private schools, where parents pay (often substantial) fees, they still receive a measure of government funding, including from federal sources (Dowling, 2007), but are governed and accountable at individual school level, as far as the state is concerned. 
Non-state schools are heterogeneous and their ownership structures vary, being divided into Catholic and independent, with the latter being a mix of Protestant, nondenominational and other (Queensland Department of Education and Training, (QDET) 2010a). Catholic schools form the largest system, and most are run by their local parish, or diocese under the auspices of the Catholic Education Commission. However, some are owned and operated by a specific Catholic order and thus are non-systemic. Independent schools are constituted separately but tend to be associated with a Protestant order and an overarching organisation (such as the Anglican Schools Commission), and are thus mostly systemic (Association of Independent Schools of Queensland (AISQ), 2010). There are also eight state grammar schools in Queensland which operate outside the normal state system. Modelled on elite grammar schools in the UK, they are a legacy of the 1800s, charge fees and have an independent governance framework enshrined in legislation (QDET, 2010b).

In 2010 there were 467 non-state schools in Queensland, with 239,636 students constituting approximately 33 per cent of enrolments and increasing (Non State Schools Accreditation Board (NSSAB), 2011). Standards for non-state schools in Queensland were established by the Education (Accreditation of Non-State Schools) Act 2001. The Act addresses broad criteria for governance arrangements and other aspects of school operations. Governance arrangements were not spelled out in detail. New Public Management (NPM) ideology is clearly evident where the NSSAB states 'the efficient allocation of public resources will be of continuing importance given the rapid rate of growth in the non-state schools sector in Queensland' (NSSAB, 2009: 1 emphasis added). This paper set out to examine governance in non-state schools, particularly in reference to structures and stakeholders. 


\section{Method}

Extant international research on educational governance employs a descriptive, qualitative design with semi-structured interviews with key informants (Brewer \& Smith, 2008; Brown \& Duku, 2008; Chikoko, 2008; Falconetti, 2009; Hay \& Kapitzke, 2009). The present study conforms to this trend, with interviews in six schools. The schools were selected to address the main ownership arrangements in Queensland, within the constraints of willingness to participate on the part of schools. Details are given in Table 1.

Table 1 Characteristics of the schools about here

In each of the six schools three key informants were interviewed: the chairperson of the board, the principal, and the business manager (with the exception of School 6 where the business manager was deemed by the chairperson as too new in the job). This resulted in seventeen interviews. The chairperson was chosen to represent the board, assuming that she/he would present the formal board position, even though it was possible that 'rank and file' board members may have divergent views. The six schools provided details of governance structures, policies and procedures, with questions around overall structure and arrangements, membership including representation, filling vacancies, skill mix, reporting, who selects the principal, induction and self evaluation. Interviews were taped, transcribed and analysed, clustering information into common categories across the schools. 
Trustworthiness of the results was improved through triangulation (three informants' views) and through comparing themes between research peers (three authors) (Healy \& Perry, 2000). General commonalities were identified and some unique practices emerged. Each school contributed to a more all-round picture of school governance, with the following findings.

\section{Findings}

The seventeen interviews produced large volumes of information about numerous aspects of governance. Owing to space limitations, this paper focuses on some elements of structure and stakeholder representation. Board membership, structure, characteristics and processes are shown in Table 2. The smallest board had seven members (School 1) and the largest mentioned was fourteen (School 5). The principal was a member of all school boards, and the board was responsible for appointing the principal in four of the six schools. In Schools 2 and 4 the owning body appointed the principal, with some input from the board.

Table 2 Board membership: structure, characteristics and processes about here

Board membership in the schools suggested three or four different types (See Table 2). The first was School 1 which is unique owing to its being one the state's eight grammar schools and thus the Minister for Education has a role in nominations. The second is School 2 where membership is more focused on the school community. Schools 3, 4 and 5 all had senior members of the church hierarchy as board members, along with 
members of the local church. In School 6 the board is very closely tied to the local church by virtue of the church's senior minister being the board chair, who appoints the board, and the board itself a subcommittee of the parish council. Thus School 6 is similar to the third type but with more narrow membership, and even tighter structural linkages to the owner.

Apart from these differences in ex-officio memberships, the schools also varied in the processes by which members joined the board (see Table 2). Schools 1, 3, 4 and 5 all implied a 'tap on the shoulder' approach where potential nominees are identified by board members and invited to apply. School 2 was unique in issuing an open invitation to the school community. Schools 3, 4 and 5 had representation from Parents and Friends groups. In contrast, parent membership at School 6 was by chair invitation only.

The schools also varied in terms of the characteristics sought in board members, with schools emphasising either skills in the professions (School 1), active religious faith to a greater or lesser degree (Schools 3, 5 and 6), or a mixture of both (Schools 2 and 4) (See Table 3).

The emphasis on skills mix is illustrated by School 1:

When looking for nominees, the board looks at the makeup of the board and the person leaving. They look to have the professions covered, such as legal, educationalist, accounting, general business perspectives; also a representative of boarding parents or rural. There is a strong recommendation to the Minister to ensure that there is continuity on the board, plus the necessary skills mix from the professions. 
The faith requirement of some schools is illustrated by School 3:

In relation to the Parish representatives they are members of the local church. There is a faith requirement which has to be expressed to the minister or to several council members. I can't remember anyone being nominated who did not fit the faith requirement.

Following on from the process of recruitment is the question of inducting board members. Schools 1-5 mentioned induction, with most being relatively informal, although this varied. For example, School 3 has a policy subcommittee explicitly concerned with how the board works and a member of this committee does the induction. School 4, being systemic, has a handbook provided by the system's Schools Office.

In terms of other aspects of stakeholder involvement and communication, School 2 involves staff indirectly via their input to the board subcommittees. School 3 involves the whole school community (students, parents, staff, the board and the church council) in planning, which was unusual compared to the other schools. Schools 4 and 5 involve senior staff in strategic planning. In terms of parent feedback, Schools 2, 3, 4 and 5 all indicated that they surveyed parents.

Details of reporting to the owners were also sought. With the exception of School 1, reports are generally monthly, along with an annual report which is a matter of compliance (School 1) or in person and in-depth, with scrutiny (School 5). Since Schools 3, 4, 5 and 6 all have owner representatives on the board, they receive reports as part of board meetings and processes. Only School 4 disseminated to the wider 
community a report that resembles annual reports issued by organisations in other sectors. Such annual reports are an important communication and accountability mechanism. In Queensland a new policy has subsequently been introduced requiring non-state schools to produce a written annual report (NSSAB, 2009). Differences in reporting can be illustrated by contrasting School 3 and School 4 as follows:

School 3: The Principal believes he has a professional obligation to be reporting to stakeholders. This is done in informal ways. About 10 times a year the Principal invites a group of parents in for a "vision" function. They look at where the school has been, where they are going and how they are travelling. The Principal reports on a monthly basis to the Council. The accountability to the wider community is more tenuous.

School 4: The annual report sets out the goals and achievements. The annual report is available at speech day and is provided to all members of the school's community.

Three schools mentioned self evaluation or a focus on board processes, including School 3, which has a policy subcommittee explicitly concerned with how the board works. School 4 has board-level policies from the (Systemic) Schools Office which dictate how the board will operate. These include checklists to follow throughout the year to fulfil the constitution. In School 5 the board has a retreat each year where reflection on the board takes place. The Director of AISQ has been leading the retreat for the last few years. 
Table 3 Characteristics of board members about here

Table 4 Summary of school governance models about here

\section{Discussion}

Appropriate models of governance

The findings suggest a range of governance models in non-state schools (See Table 4). In terms of existing state models, some of the non-state schools were similar in some respects. However, additional models may be needed. The democratic model where an elected board is committed to citizen voice and representing the interests of their constituents (Allen \& Mintrom, 2010), is relevant to School 2. The trustee model in which competence and effectiveness in managing resources are significant (Allen \& Mintrom, 2010), describes School 1, and to a lesser extent Schools 2 and 4. Since School 2 also resembled the democratic model a hybrid of the trustee plus democracy model seems appropriate. There are other typologies in the literature, such as a business model which argues that owing to the large budgets of schools they should be governed by a small executive body with experience in running organisations along business lines. This body may still include people from the community with requisite skills (Jones \& Ranson, 2010), and appears like the trustee and democracy models of Allen and Mintrom (2010).

Another model sees decision-making decentralised to schools and families (Allen \& Mintrom, 2010). This was not observed in the schools (with the limited exception of School 3, where members of the whole school community were involved in annual planning). Indeed, one of the notable features in the results was the high degree of 
centralisation not just at board level, but also at church level, by virtue of close ties between ownership structures and board structures (with common membership).

None of the existing models seem entirely appropriate for non-state schools. For some an additional requirement is to maintain the values and ethos of the faith. This faith may exist to varying degrees along a spectrum of relatively laissez fair subscription to nominal Christian values (School 1), through relatively rigorous practices to ensure that board members are active in the faith (Schools 3 and 5), to a proactive approach where the explicit mission of the school is to make disciples or converts (School 6). Thus an additional faith model could be added to the literature.

\section{Accountability to a range of stakeholders}

Engagement with other stakeholders across the schools could be described as ad hoc, since most important stakeholders were involved, but no one school engaged them all. Overall, there may be an over-preoccupation with owning and governing stakeholders at the expense of others, particularly students, parents, the wider school community and governments who provide partial funding. Indeed, what is quite remarkable in the interviews is virtually a complete absence of any mention of governments, (with the exception of School 1, the grammar school and even in this case the implication was 'lip service'), even though they are a stakeholder by virtue of funding.

Thus school boards could do more to meet current state based notions of governance in terms of engaging stakeholders, such as in the relationship governance model, where stakeholders have a say in board membership (Bhasa, 2005). Involvement of staff 
and students in governance has been advocated in the literature for at least thirty-two years (Treslan, 1979). Decentralisation and local representation on school boards is a significant trend in the international literature, and democratic election of school boards has been recommended in Australia (Allan, 2006). Engaging a broader range of stakeholders is an area for school board improvement (Sheard \& Avis, 2011; Youngs et al., 2007) and for sustainable school principalship (Drysdale et al., 2009). Yet in these schools students were the least acknowledged voice. It may be that the patriarchal and hierarchical models of the faith-based owning bodies of some non-state schools mitigate against involvement and empowerment. There are many obstacles, including traditional culture and hierarchy (Adams et al., 2009; Ryan \& Rottmann, 2009), which seem evident in some of these schools' governance structures and processes.

\section{Limitations and implications for further research}

This research was restricted to six non-state schools in one Australian state. The study was exploratory, and the description of governance structures and processes and the suggested new type should be tested in other states, and in other countries. The governance elements and the notion of a governance model based on 'keeping the faith' could be operationalised in a survey to enable more extensive, quantitative analysis. How faith-based governance impacts on school effectiveness, along the lines of the Framework for Enhancing School Outcomes (Andrews et al., 2004) could also be examined.

Views of 'rank and file' board members could be sought, and the process of selecting the principal could also be examined as the focus here was on selecting other board 
members. Only a narrow range of governance elements was addressed in this paper, and therefore it would be enlightening to research the opinion of students, parents, staff and other stakeholders on the extent of their involvement in and representation on nonstate school governance structures and processes, particularly in those schools that have highly centralised and relatively closed structures. It would be interesting to conduct a longitudinal analysis of non-state school governance to see if isomorphism towards more business-like models develops, depending on any future government efforts to increase control.

There are also significant questions and issues underlying this and other governance research in terms of comparisons between state and non-state schools, the significance and purpose of education, the ideology that underpins each system, what constitutes effectiveness, the implications for governance and why this might or should be varied across systems.

\section{Conclusion}

Non-state schools comprise around one third of schools in Queensland and the number is growing. Government has expressed some intention to increase regulation, partly reflecting international trends in the state sector. This paper explored governance structures and processes in non-state schools and found the schools are not homogeneous. Further, even though they are decentralised according to notions of governance from the state system, they appeared quite centralised in practice. There were tight structural linkages between school owners (churches) and school boards in some cases. Few schools exhibited completely democratic processes in terms of 
opening board membership to the school or wider communities, yet there were exceptions. More schools could engage with more stakeholders more systematically.

Existing typologies of state schools governance may need to be extended for these schools. Our research suggests that the existing models are somewhat useful and relevant for describing non-state schools, particularly the trustee model. However, more dimensions and variations are needed and the typology could be expanded to include a faith model.

\section{References}

ACARA (2009) 'National curriculum', Sydney: Australian Curriculum, Assessment and Reporting Authority. Online: http://www.acara.edu.au/default.asp [accessed December 2010]

Ackerman, J. (2004) 'Co-governance for accountability: Beyond 'exit' and 'voice'. World Development, 32(3), 447-463.

Adams, C. M., Forsyth, P. B. \& Mitchell, R. M. (2009) 'The formation of parent-school trust: A multilevel analysis'. Educational Administration Quarterly, 45(1), 4-33.

Addi-Raccah, A. \& Gavish, Y. (2010) 'The leaders' role in a decentralized school system: The school principal's view'. Educational Management Administration \& Leadership, 38(2), 184-201. 
AISQ (2010) 'About independent schools'. Brisbane: Association of Independent Schools of Queensland. Online:

http://www.aisq.qld.edu.au/Page2.aspx?element=14\&category=1 [accessed February 2011]

Alfred, R. L. \& Smydra, D. F. (1985) Reforming governance: Resolving challenges to institutional authority. In W. Deegan \& D. Tillery (eds.) Renewing the American Community College. San Francisco: Jossey-Bass.

Allan, J. (2006) 'Response to the review of school governance in Victorian government schools'. Melbourne: Office of Strategy and Review, Department of Education and Training. Online:

http://www.det.vic.gov.au/edulibrary/public/teachlearn/projects/schoolgov/Response_S choolGovernance_in_VicGovSchools-rpt.pdf [accessed October 2009]

Allen, A. \& Mintrom, M. (2010) 'Responsibility and school governance'. Educational Policy, 24(3), 439-464.

Amey, M. J., Jessup-Anger, E. \& Jessup-Anger, J. (2008) 'Community college governance: What matters and why?'. New Directions for Community Colleges, 141(1), 5-14.

Andrews, D., Conway, J., Dawson, M., Lewis, J., McMaster, M. A. \& Starr, H. (2004) 'School revitalisation the IDEAS Way' (ACEL Monograph Series). Melbourne: ACEL. 
Ball, S. J. (2009) 'The governance turn!'. Journal of Education Policy, 24(5), 537-538.

Banks, G. (2005) 'Comparing school systems across Australia'. Paper presented at ANZSOG conference, Sydney, September.

Bhasa, M. P. (2005) 'Understanding the corporate governance quadrilateral'. Corporate Governance, 4(2), 7-15.

Brewer, D. J. \& Smith, J. (2008) 'A framework for understanding educational governance: The case of California'. Education Finance and Policy, 3(1), 20-40.

Brown, B. A. \& Duku, N. S. (2008) 'Participation politics: African parents' negotiation of social identities in school governance and its policy implications'. International Journal of Lifelong Education, 27(4), 413-429.

BRT (2002) Principles of corporate governance. Washington, DC: The Business Roundtable.

Bush, T. \& Gamage, D. (2001) 'Models of self-governance in schools: Australia and the United Kingdom'. International Journal of Educational Management, 15(1), 39-44.

Carver, J. (1997) Boards that make a difference: A new design for leadership in nonprofit and public organizations. San Francisco: Jossey-Bass. 
Chikoko, V. (2008) 'The role of parent governors in school governance in Zimbabwe: Perceptions of school heads, teachers and parent governors'. International Review of Education, 54(2), 243-263.

Coyle, B. (2004) Risk awareness and corporate governance. 2nd ed, Canterbury: Financial World Publishing.

Dahlstedt, M. (2009) 'Governing by partnerships: Dilemmas in Swedish education policy at the turn of the millennium'. Journal of Education Policy, 24(6), 787-801.

Donaldson, T. \& Preston, L. E. (1995) 'The stakeholder theory of the corporation: Concepts, evidence and implications'. Academy of Management Review, 20(1), 6591.

Dowling, A. (2007) 'Australia's school funding system' (ACER Policy Briefs). Melbourne: Australian Council for Educational Research.

Drysdale, L., Goode, H. \& Gurr, D. (2009) 'An Australian model of successful school leadership: Moving from success to sustainability'. Journal of Educational Administration, 47(6), 697-708.

Eacott, S. (2008) 'An analysis of contemporary literature on strategy in education'. International Journal of Leadership in Education, 11(3), 257-280. 
Edwards, D. B., (2010) 'Trends in governance and decision-making: A democratic analysis with attention to application in education'. Policy Futures in Education, 8(1), 111-125.

Engel, L. C. (2008) 'Breaking the centre-periphery mould: Exploring globalisation and educational governance in Catalonia'. Globalisation, Societies and Education, 6(3), 265-279.

Falconetti, A. M. G. (2009) 'The perceived effects of state governance decentralization on Baccalaureate articulation'. Community College Journal of Research and Practice, 33(2), 177-194.

Grant, S. (2006) 'Community (not-for-profit) governance: What are some of the issues?'. Third Sector Review, 12(1), 39-56.

Gruber, G. (1999) Rural education program. Brisbane: Charter Starters Leadership Training.

Hay, S. (2009) 'Transforming social and educational governance: Trade Training Centres and the transition to social investment politics in Australia'. British Journal of Educational Studies, 57(3), 285-304.

Hay, S. \& Kapitzke, C. (2009) 'Industry school partnerships: Reconstituting spaces of educational governance'. Globalisation, Societies and Education, 7(2), 203-216. 
Healy, M. \& Perry, C. (2000) 'Comprehensive criteria to judge the validity and reliability of qualitative research within the realism paradigm'. Qualitative Market Research: An International Journal, 3(3), 118-126.

Jones, J. \& Ranson, S. (2010) 'Reconfiguring the governance of schools in England'. Management in Education, 24(1), 7-13.

Kiel, G. \& Nicholson, G. (2003) Boards that work. Sydney: McGraw Hill.

Lo, W. Y. W. \& Gu, J. O. (2008) 'Reforming school governance in Taiwan and South Korea: Empowerment and autonomization in school-based management'. International Journal of Educational Management, 22(6), 506-526.

London, J. D. (2010) 'Globalization and the governance of education in Viet Nam’. Asia Pacific Journal of Education, 30(4), 361-379.

Newell, R. \& Wilson, G. (2002) 'A premium for good governance'. The McKinsey Quarterly, 3, 20-23.

NSSAB (2009) Non-State Schools Accreditation Board. Brisbane: NSSAB.

NSSAB (2011) Non-State Schools Accreditation Board. Update. Brisbane: NSSAB. 
OECD (1999) Principles of corporate governance. Paris: OECD.

Picou, A. \& Rubach, M. J. (2006) 'Does good governance matter to institutional investors? Evidence from the enactment of corporate governance guidelines'. Journal of Business Ethics, 65(1), 55-67.

QDET (2010a) 'Schools in Queensland', Brisbane: Queensland Department of Education and Training. Online: http://education.qld.gov.au [accessed December 2010]

QDET (2010b) 'The Grammar schools era 1860-1912', Brisbane: Queensland Department of Education and Training, Queensland Government Library. Online: http://education.qld.gov.au/library/edhistory/state/brief/secondary-1860.html [accessed December 2010]

Ranson, S. (2008) 'The changing governance of education'. Educational Management, Administration \& Leadership, 36(2), 201-219.

Ryan, J. \& Rottmann, C. (2009) 'Struggling for democracy: Administrative communication in a diverse school context'. Educational Management Administration \& Leadership, 37(4), 473-496.

Salleh, A., Ahmad, A. \& Kumar, N. (2009) 'Human governance: A neglected mantra for continuous performance improvement'. Performance Improvement, 48(9), 26-30. 
Sheard, M. \& Avis, J. (2011) 'Schools, governance and community: A next practice intervention'. Educational Management Administration \& Leadership, 39(1), 84-104.

Stoker, G. (1998) 'Governance as theory: five propositions'. International Social Science Journal, 50(155), 17-28.

Storey, V. A. \& Farrar, M. (2009) 'The new localism in the UK: Local governance amid national goals'. Yearbook of the National Society for the Study of Education, 108(1), 1-20.

Treslan, D. L. (1979) 'Toward an ideal senior high school governance structure'. High School Journal, 63(1), 17-22.

Turkington, M. (1998) 'Self-managing schools: will the 'have-nots' manage?'. Directions in Education, 7(7), 3-4.

Tweeten, B. L. (2002) Transformational boards. San Francisco: Jossey Bass.

Youngs, H., Cardno, C., Smith, A. \& France, C. (2007) 'Governance leadership in New Zealand schools: The perceptions of board chairs in relation to their role and development needs'. Leading and Managing, 13(1), 49-65.

Zattoni, A. \& Cuomo, F. (2008) 'Why adopt codes of good governance? A comparison of institutional and efficiency perspectives'. Corporate Governance: An International Review, 16(1), 1-15. 
Table 1 Characteristics of the schools

\begin{tabular}{|c|c|c|c|c|c|}
\hline School & Religion & Ownership & School type & Day/boarding & $\begin{array}{l}\text { Year } \\
\text { levels }\end{array}$ \\
\hline $\begin{array}{l}\text { School } \\
1\end{array}$ & $\begin{array}{l}\text { Nominal } \\
\text { Christian }\end{array}$ & $\begin{array}{l}\text { One of } 8 \text { grammar } \\
\text { schools. The } \\
\text { Board of Trustees } \\
\text { is constituted } \\
\text { under Grammar } \\
\text { Schools Act } 1975\end{array}$ & Single sex & $\begin{array}{l}\text { Day and } \\
\text { boarding }\end{array}$ & $\begin{array}{l}\text { Primary } \\
\text { and } \\
\text { secondary }\end{array}$ \\
\hline $\begin{array}{l}\text { School } \\
2\end{array}$ & Catholic & $\begin{array}{l}\text { Non systemic, } \\
\text { owned by } \\
\text { religious order, } \\
\text { incorporated } \\
\text { separately }\end{array}$ & Coeducational & $\begin{array}{l}\text { Day and } \\
\text { boarding }\end{array}$ & Secondary \\
\hline $\begin{array}{l}\text { School } \\
3\end{array}$ & Christian & $\begin{array}{l}\text { Non systemic, } \\
\text { unincorporated, } \\
\text { operated by local } \\
\text { parish, governed } \\
\text { by church's state } \\
\text { level governing } \\
\text { body }\end{array}$ & Coeducational & Day & $\begin{array}{l}\text { Primary } \\
\text { and } \\
\text { secondary }\end{array}$ \\
\hline $\begin{array}{l}\text { School } \\
4\end{array}$ & $\begin{array}{l}\text { Mainstream } \\
\text { Protestant }\end{array}$ & $\begin{array}{l}\text { Systemic, a Pty } \\
\text { Ltd company with } \\
1 \text { shareholder } \\
\text { being the }\end{array}$ & Single sex & $\begin{array}{l}\text { Day and } \\
\text { boarding }\end{array}$ & $\begin{array}{l}\text { Primary } \\
\text { and } \\
\text { secondary }\end{array}$ \\
\hline
\end{tabular}




\begin{tabular}{|c|c|c|c|c|c|}
\hline & & auspicing Church & & & \\
\hline $\begin{array}{l}\text { School } \\
5\end{array}$ & $\begin{array}{l}\text { Mainstream } \\
\text { Protestant }\end{array}$ & $\begin{array}{l}\text { Non-systemic, } \\
\text { separately } \\
\text { incorporated and } \\
\text { wholly owned by } \\
\text { the Church, a } \\
\text { Diocesan school }\end{array}$ & Single sex & $\begin{array}{l}\text { Day and } \\
\text { boarding }\end{array}$ & $\begin{array}{l}\text { Primary } \\
\text { and } \\
\text { secondary }\end{array}$ \\
\hline $\begin{array}{l}\text { School } \\
6\end{array}$ & $\begin{array}{l}\text { Mainstream } \\
\text { Protestant }\end{array}$ & $\begin{array}{l}\text { Non-systemic, } \\
\text { unincorporated, } \\
\text { operated by the } \\
\text { local parish of the } \\
\text { church, which } \\
\text { belongs to the } \\
\text { state Synod of the } \\
\text { church }\end{array}$ & Coeducational & Day & $\begin{array}{l}\text { Primary } \\
\text { and } \\
\text { Secondary }\end{array}$ \\
\hline
\end{tabular}


Table 2 Board membership: structure, characteristics and processes

\begin{tabular}{|l|l|l|l|l|l|l|}
\hline & School 1 & School 2 & School 3 & School 4 & School 5 \\
& Grammar & Catholic, non-systemic & Christian & Mainstream Protestant & Mainstream \\
Protestant & & & Christian \\
\hline
\end{tabular}




\begin{tabular}{|c|c|c|c|c|c|c|}
\hline & $\begin{array}{l}\text { School } 1 \\
\text { Grammar }\end{array}$ & $\begin{array}{l}\text { School } 2 \\
\text { Catholic, non-systemic }\end{array}$ & $\begin{array}{l}\text { School } 3 \\
\text { Christian }\end{array}$ & $\begin{array}{l}\text { School } 4 \\
\text { Mainstream Protestant }\end{array}$ & $\begin{array}{l}\text { School } 5 \\
\text { Mainstream } \\
\text { Protestant }\end{array}$ & $\begin{array}{l}\text { School } 6 \\
\text { Christian }\end{array}$ \\
\hline $\begin{array}{l}\text { Board } \\
\text { membership }\end{array}$ & $\begin{array}{l}\text { Four members } \\
\text { appointed by state } \\
\text { Minister for } \\
\text { Education, three } \\
\text { elected. }\end{array}$ & $\begin{array}{l}\text { Members of school } \\
\text { community }\end{array}$ & $\begin{array}{l}\text { About } 8 \\
\text { representatives } \\
\text { from local church } \\
\text { appointed by parish } \\
\text { council. A Synod } \\
\text { representative and } \\
\text { also a Presbytery } \\
\text { representative. } \\
\text { Minister of local } \\
\text { church is part of the } \\
\text { board by virtue of } \\
\text { office. }\end{array}$ & $\begin{array}{l}\text { Archbishop has } \\
\text { representative of } \\
\text { Diocese on board. } \\
\text { Also a representative } \\
\text { of the church's } \\
\text { Schools Office. }\end{array}$ & $\begin{array}{l}14 \text { members. } \\
\text { Owners have direct } \\
\text { representation: } \\
\text { Moderator of the } \\
\text { church, Clerk of } \\
\text { Assembly and } \\
\text { General Secretary } \\
\text { ex officio. Two } \\
\text { members of local } \\
\text { Presbytery. Two } \\
\text { members of } \\
\text { church's board of }\end{array}$ & $\begin{array}{l}\text { Senior Pastor } \\
\text { of parish is } \\
\text { automatically } \\
\text { chair. }\end{array}$ \\
\hline
\end{tabular}




\begin{tabular}{|c|c|c|c|c|c|c|}
\hline & $\begin{array}{l}\text { School } 1 \\
\text { Grammar }\end{array}$ & $\begin{array}{l}\text { School } 2 \\
\text { Catholic, non-systemic }\end{array}$ & $\begin{array}{l}\text { School } 3 \\
\text { Christian }\end{array}$ & $\begin{array}{l}\text { School } 4 \\
\text { Mainstream Protestant }\end{array}$ & $\begin{array}{l}\text { School } 5 \\
\text { Mainstream } \\
\text { Protestant }\end{array}$ & $\begin{array}{l}\text { School } 6 \\
\text { Christian }\end{array}$ \\
\hline & & & & & finance. & \\
\hline Board & Casual vacancies & Onen request to school & Iocal church & Under conctitution & Annointmont & Iltimato \\
\hline Board & Casual vacancies & Upen request to school & Local cnurch & Under constitution, & Appointment & Uitimate \\
\hline membership & filled on & community for & council nominate to & Synod appoints board, & confirmed each & responsibility \\
\hline - process for & recommendation of & expression of interest & board who then & including chair. & year by Assembly & for selecting \\
\hline determining & board. Board & to the board. The & nominate to Synod. & Usually take the & of the Church. & board members \\
\hline membership & arranges panel of & school community & Council talks to & board's & Names are brought & rests with the \\
\hline and filling & suitable applicants. & includes teachers, past & nominees. Council & recommendation. & forward by existing & chair. \\
\hline \multirow[t]{5}{*}{ vacancies } & Principal is aware & students, students (if & or minister will be & Board members are & members. Board & Board do meet \\
\hline & of nominations and & over 18), Applicant's & very familiar with & selected by word of & can be pretty & with \\
\hline & expresses a & letter and & nominees - no need & mouth. Talking to & confident that & prospective \\
\hline & preference. & accompanying $\mathrm{CV}$ and & for formal & people in the & names would not be & candidates \\
\hline & Chair approaches & references. & interview. Parents & community who have & brought forward if & several times \\
\hline
\end{tabular}




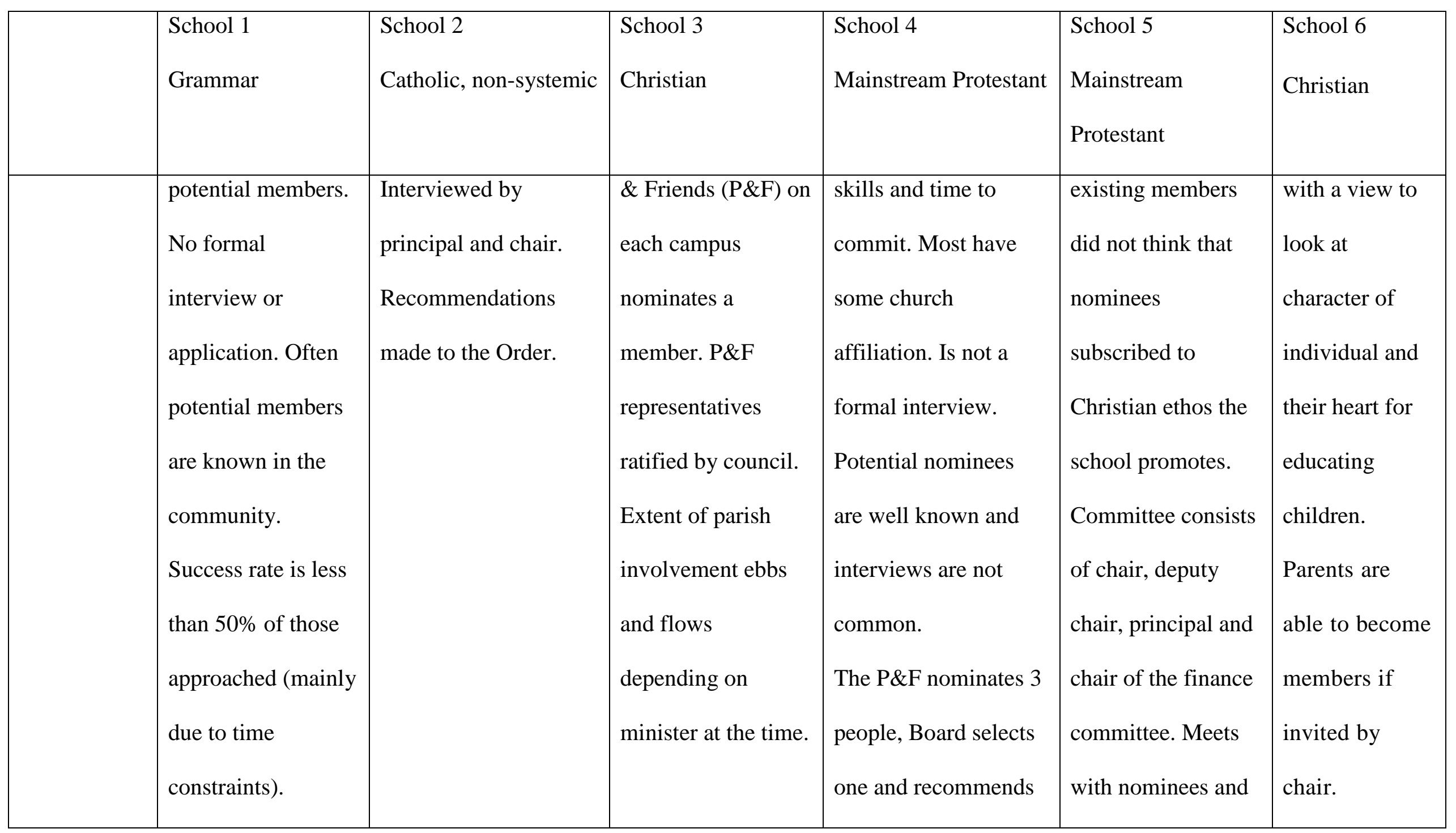




\begin{tabular}{|c|c|c|c|c|c|}
\hline $\begin{array}{l}\text { School } 1 \\
\text { Grammar }\end{array}$ & $\begin{array}{l}\text { School } 2 \\
\text { Catholic, non-systemic }\end{array}$ & $\begin{array}{l}\text { School } 3 \\
\text { Christian }\end{array}$ & $\begin{array}{l}\text { School } 4 \\
\text { Mainstream Protestant }\end{array}$ & $\begin{array}{l}\text { School } 5 \\
\text { Mainstream } \\
\text { Protestant }\end{array}$ & $\begin{array}{l}\text { School } 6 \\
\text { Christian }\end{array}$ \\
\hline & & & them. & $\begin{array}{l}\text { discusses type of } \\
\text { person board is } \\
\text { looking for, extent } \\
\text { of commitment. } \\
\text { Process provides } \\
\text { sufficient checks } \\
\text { and balances. A } \\
\text { representative from } \\
\text { P\&F. Some } \\
\text { members of the } \\
\text { board are current } \\
\text { parents. }\end{array}$ & \\
\hline
\end{tabular}


Table 3 Characteristics of board members

\begin{tabular}{|c|c|c|c|c|c|c|}
\hline & School 1 & School 2 & School 3 & School 4 & School 5 & School 6 \\
\hline $\begin{array}{l}\text { Characteristics } \\
\text { of board } \\
\text { members }\end{array}$ & $\begin{array}{l}\text { Board looks at makeup } \\
\text { of board and person } \\
\text { leaving. Look to have } \\
\text { professions covered, } \\
\text { such as legal, } \\
\text { educationalist, } \\
\text { accounting, general } \\
\text { business perspectives; } \\
\text { also a representative of } \\
\text { boarding parents or rural. } \\
\text { Strong recommendation } \\
\text { to Minister to ensure } \\
\text { continuity plus necessary }\end{array}$ & $\begin{array}{l}\text { Chair and } \\
\text { principal look at } \\
\text { skills mix } \\
\text { remaining and } \\
\text { match, as close } \\
\text { as possible, } \\
\text { required skills } \\
\text { mix with } \\
\text { applicant. Board } \\
\text { members have to } \\
\text { accept and not be } \\
\text { in opposition to } \\
\text { the Order's }\end{array}$ & $\begin{array}{l}\text { Only criteria for } \\
\text { members are that } \\
\text { they are acceptable to } \\
\text { members of local } \\
\text { church - they are } \\
\text { worshipping } \\
\text { members. Parish } \\
\text { representatives are } \\
\text { members of local } \\
\text { church. Faith } \\
\text { requirement which } \\
\text { has to be expressed } \\
\text { to the minister or to }\end{array}$ & $\begin{array}{l}\text { Chair and deputy } \\
\text { chair identify } \\
\text { suitable candidates, } \\
\text { often looking to } \\
\text { replace the skill sets } \\
\text { of who is leaving. } \\
\text { Explicit recognition } \\
\text { of skills gap. Try } \\
\text { and get a cross- } \\
\text { section of people. A } \\
\text { lawyer, accountant, } \\
\text { marketing. Cross- } \\
\text { section of thought }\end{array}$ & $\begin{array}{l}\text { Majority of board } \\
\text { must be } \\
\text { communicant } \\
\text { members of church: } \\
\text { protection to ensure } \\
\text { board implements } \\
\text { ethos. No-one can } \\
\text { serve who is not } \\
\text { practicing member of } \\
\text { Christian } \\
\text { congregation (except } \\
\text { P\&F representatives). }\end{array}$ & $\begin{array}{l}\text { Members of } \\
\text { board do not } \\
\text { have to } \\
\text { attend } \\
\text { sponsoring } \\
\text { church, but } \\
\text { must be } \\
\text { Christians. }\end{array}$ \\
\hline
\end{tabular}




\begin{tabular}{|c|c|c|c|c|c|c|}
\hline & School 1 & School 2 & School 3 & School 4 & School 5 & School 6 \\
\hline & $\begin{array}{l}\text { skills mix from } \\
\text { professions. Board is } \\
\text { continually looking at } \\
\text { skills mix required so } \\
\text { that board has a range of } \\
\text { expertise. }\end{array}$ & philosophies & $\begin{array}{l}\text { several council } \\
\text { members. } \\
\text { No clear criteria for } \\
\text { P\&F members - they } \\
\text { are nominated by the } \\
\text { P\&F. There is no } \\
\text { skills audit or } \\
\text { analysis in the } \\
\text { process of selection. }\end{array}$ & $\begin{array}{l}\text { and views. A range } \\
\text { of interests: people } \\
\text { of high standing in } \\
\text { local community. At } \\
\text { least half have to be } \\
\text { practising (the } \\
\text { systemic religion). } \\
\text { Members must sign } \\
\text { that they adopt and } \\
\text { abide by Ethos } \\
\text { Statement. }\end{array}$ & & \\
\hline
\end{tabular}

Table 4 Summary of school governance models 


\begin{tabular}{|c|c|c|c|c|c|c|}
\hline & School 1 & School 2 & School 3 & School 4 & School 5 & School 6 \\
\hline $\begin{array}{l}\text { Board } \\
\text { appoints } \\
\text { principal }\end{array}$ & & No & & No & & \\
\hline Size & Smallest 7 & & & & Largest 14 & \\
\hline Membership & $\begin{array}{l}\text { Education } \\
\text { Minister } \\
\text { involvement }\end{array}$ & $\begin{array}{l}\text { School } \\
\text { community }\end{array}$ & $\begin{array}{l}\text { Church } \\
\text { hierarchy } \\
\text { membership }\end{array}$ & $\begin{array}{l}\text { Church } \\
\text { hierarchy } \\
\text { membership }\end{array}$ & $\begin{array}{l}\text { Church } \\
\text { hierarchy } \\
\text { membership }\end{array}$ & $\begin{array}{l}\text { Church and } \\
\text { School Board } \\
\text { closest ties }\end{array}$ \\
\hline $\begin{array}{l}\text { How } \\
\text { members join }\end{array}$ & $\begin{array}{l}\text { Tap on } \\
\text { shoulder }\end{array}$ & $\begin{array}{l}\text { Open to } \\
\text { school } \\
\text { community }\end{array}$ & $\begin{array}{l}\text { Tap on } \\
\text { shoulder } \\
\text { P\&F }\end{array}$ & $\begin{array}{l}\text { Tap on } \\
\text { shoulder } \\
\text { P\&F }\end{array}$ & $\begin{array}{l}\text { Tap on } \\
\text { shoulder } \\
\text { P\&F }\end{array}$ & $\begin{array}{l}\text { Chair } \\
\text { invitation } \\
\text { only }\end{array}$ \\
\hline $\begin{array}{l}\text { Member } \\
\text { characteristics }\end{array}$ & $\begin{array}{l}\text { Skill in } \\
\text { professions }\end{array}$ & $\begin{array}{l}\text { Skill in } \\
\text { professions } \\
\text { Active } \\
\text { religious faith }\end{array}$ & $\begin{array}{l}\text { Active } \\
\text { religious faith }\end{array}$ & $\begin{array}{l}\text { Skill in } \\
\text { professions } \\
\text { Active } \\
\text { religious faith }\end{array}$ & $\begin{array}{l}\text { Active } \\
\text { religious faith }\end{array}$ & $\begin{array}{l}\text { Active } \\
\text { religious faith }\end{array}$ \\
\hline
\end{tabular}




\begin{tabular}{|c|c|c|c|c|c|c|}
\hline Induction & Informal & Informal & More formal & More formal & Informal & \\
\hline $\begin{array}{l}\text { Staff } \\
\text { involvement }\end{array}$ & & $\begin{array}{l}\text { Staff input to } \\
\text { board } \\
\text { subcommittees }\end{array}$ & $\begin{array}{l}\text { Whole school } \\
\text { community } \\
\text { involved in } \\
\text { planning }\end{array}$ & $\begin{array}{l}\text { Senior staff } \\
\text { involved in } \\
\text { planning }\end{array}$ & $\begin{array}{l}\text { Senior staff } \\
\text { involved in } \\
\text { planning }\end{array}$ & \\
\hline $\begin{array}{l}\text { Surveyed } \\
\text { parents }\end{array}$ & & Yes & Yes & Yes & Yes & \\
\hline Reporting & $\begin{array}{l}\text { Compliance } \\
\text { - to } \\
\text { Minister }\end{array}$ & & $\begin{array}{l}\text { to owner via } \\
\text { representation } \\
\text { on board }\end{array}$ & $\begin{array}{l}\text { to owner via } \\
\text { representation } \\
\text { on board }\end{array}$ & $\begin{array}{l}\text { to owner via } \\
\text { representation } \\
\text { on board } \\
\text { In person, } \\
\text { with scrutiny } \\
\text { from parish }\end{array}$ & $\begin{array}{l}\text { to owner via } \\
\text { representation } \\
\text { on board }\end{array}$ \\
\hline $\begin{array}{l}\text { Widely } \\
\text { available }\end{array}$ & & & & Yes & & \\
\hline
\end{tabular}




\begin{tabular}{|l|l|l|l|l|l|l|}
\hline annual report & & & & & \\
evaluation of & & & Via policy & Via Systemic & Annual & \\
board & & & subcommittee & Board Policy & retreat & \\
processes & & & documents & & \\
\hline Tentative fit & Trustee & Democratic & Decentralised/ & Trustee & New faith & New faith \\
mith existing & model & model/ & democratic & model & model & model \\
\hline
\end{tabular}

